удК 930(517.3)

А. П. Суходолов

Байкальский государственный университет

2. Иркутск, Российская Федерация

Ю. В. Кузьмин

Байкальский государственный университет, 2. Иркутск, Российская Федерация

В. А. Василенко

Иркутский государственный университет, г. Иркутск, Российская Федерация

\title{
ПРОБЛЕМЫ ИСТОРИИ, ИСТОЧНИКОВЕДЕНИЯ И ИСТОРИОГРАФИИ МОНГОЛИИ: К 90-ЛЕТИЮ АКАДЕМИКА ШАГДАРЫН БИРА
}

\begin{abstract}
АНнотАЦия. Представлена краткая творческая биография академика Ш. Биры, заслуженного деятеля Академии наук Монголии, почетного доктора Московского государственного института международных отношений, почетного профессора университета Внутренней Монголии, почетного члена общества изучения Центральной Азии США, почетного доктора Института Востоковедения РАН. За многолетний период своей научной и творческой деятельности ученый основал несколько новых направлений исторического исследования монгольских народов и культурного наследия Монголии, включая историческое и литературное наследие монгольского мира, историю и источниковедение Монгольской империи, тэнгрианство, научное наследие Рерихов. Его труды и идеи получили мировое признание, опубликованы на основных языках мира, активно изучаются в центрах монголоведения мира, с интересом читаются любителями монгольской истории и культуры. В статье представлена характеристика основных работ ученого, ведущего историка Монголии, крупного историографа и источниковеда. Показан значительный вклад Ш. Биры в национальное и мировое монголоведение. Определены основные направления творческой деятельности историка и научные достижения монгольского ученого.

КЛЮЧЕВЫЕ СЛОВА. Ш. Бира; история Монголии; историография и источниковедение; юбилей ученого; творческая биография; историческая наука Монголии. ИНФОРМАЦИЯ О СТАТЬЕ. Дата поступления 14 апреля 2017 г.; дата принятия к печати 4 мая 2017 г.; дата онлайн-размещения 15 июня 2017 г.
\end{abstract}

A. P. Sukhodolov Baikal State University, Irkutsk, Russian Federation

Yu. V. Kuzmin

Baikal State University, Irkutsk, Russian Federation

V. A. Vasilenko

Irkutsk State University, Irkutsk, Russian Federation

\section{PROBLEMS OF HISTORY, SOURCE STUDIES AND HISTORIOGRAPHY OF MONGOLIA:} ON 90-TH ANNIVERSARY OF ACADEMICIAN SHAGDARYN BIRA

ABSTRACT. The article presents a brief biography of the academician Sh. Bira, Honored Worker of the Academy of Sciences of Mongolia, Honorary Doctor of the Moscow State Institute of International Relations, Honorary Professor of Inner Mongolia

(C) А. П. Суходолов, Ю. В. Кузьмин, В. А. Василенко, 2017

\section{Baikal Research Journal}

электронный научный журнал Байкальского государственного университета 
University, Honorary Member of USA Society for Study of Central Asia, Honorary Doctor of Institute of Oriental Studies of RAS. For a long period of his scientific and creative activity the scientist founded several new directions of historical research of Mongolian peoples and cultural heritage of Mongolia, including the historical and literary legacy of the Mongol world, the history and source studies of the Mongol Empire, Tengrianism, scientific heritage of the Roerichs. His writings and ideas have received international recognition, have been published in the major languages of the world, are actively studied in the world centers of Mongolian studies, are read with interest by lovers of Mongolian history and culture. The article presents characteristics of the main works of the scientist, a leading historian of Mongolia, a major historiographer and source studies expert. It shows a significant contribution of Sh. Bira into the national and global Mongolian Studies, specifies the main directions of the historian's creative activity and scientific achievements of the Mongolian scientist. KEYWORDS. Sh. Bira; history of Mongolia; historiography and source studies; anniversary celebration of the scientist; performer's resume; historical science of Mongolia. ARTICLE INFO. Received March 28, 2017; accepted April 18, 2017; available online June 15, 2017.

В 2017 г. исполняется 90 лет со дня рождения самого известного монгольского историка, лауреата Государственной премии Монголии, Героя труда Монголии, доктора исторических наук, академика Шагдарын Бира. Самый знаменитый современный историк Монголии, крупный специалист по историографии и источниковедению истории Монголии, формальный и неформальный лидер современной гуманитарной научной мысли Монголии встречает свой юбилей за рабочим столом и готовит к публикации многотомное собрание сочинений своих трудов.

Длительное время академик Ш. Бира являлся Генеральным секретарем Международной ассоциации монголоведов мира, организовал и провел несколько крупных международных форумов и конгрессов монголоведения, опубликовал значительное число фундаментальных трудов по истории, философии, культуре монгольского мира. Знаменитый монгольский ученый основал несколько новых направлений исторического исследования монгольских народов и культурного наследия Монголии: историческое и литературное наследие монгольского мира, история и источниковедение Монгольской империи, тэнгрианство, научное наследие Рерихов.

Шагдарын Бира-гуай родился в 1927 г. в Улан-Баторе в образованной и интеллигентной семье. Б. Шагдар был состоятельным и обеспеченным человеком, имел много скота и занимался перевозкой грузов по «чайному пути». Семья имела добротный европейского типа дом в центре монгольской столицы. Его отец Б. Шагдар принимал активное участие в национальной борьбе монголов за освобождение от маньчжуров в 1910-х гг. [1]. Ш. Бира рано осиротел: в 10 лет он потерял отца, который был необоснованно репрессирован в 1937 г., а через три года и мать. Он жил и воспитывался в семье дяди Лувсанвандана, научного работника Книжной палаты, который привил интерес к книжной культуре и традиционным ценностям монголов [Там же].

В школьные годы он не только получил обычное среднее образование, но и изучал тибетский язык у лам. Интерес к традиционной монгольской культуре и историческому книжному наследию монголов возник уже в школьные годы. После окончания средней школы в 1946-1951 гг. учился в Советском Союзе, элитном учебном заведении - Московском государственном институте международных отношений (МГИМО). После успешного завершения обучения в МГИМО открывалась прямая дорога в профессиональные дипломаты и карьерная служба в Министерстве иностранных дел Монголии. Однако молодой выпускник престижного вуза выбирает тернистый путь ученого. Дипломатические знания и навыки

\section{Baikal Research Journal}

электронный научный журнал Байкальского государственного университета 
пригодятся ему позднее, в научном общении, переписке и развитии научного сотрудничества монголоведов мира.

С 1953 г. активно занимается исследовательской работой: с 1953 по 1957 г. преподавал историю международных отношений в Высшей партийной школе, а в 1957-1960 гг. обучается в аспирантуре Института востоковедения Академии наук. Научный руководителем аспиранта Ш. Биры стал знаменитый российский востоковед Юрий Николаевич Рерих, только что вернувшийся в СССР из Индии с прекрасной библиотекой по востоковедению и коллекцией картин. Это стало большой удачей для начинающего ученого. Ю. Н. Рерих - ученый мирового уровня, владевший всеми европейскими и основными восточными языками, был крупным тибетологом и монголоведом. Вместе с небольшой группой аспирантов и учеников Ю. Н. Рериха, он три года изучает основательно санскрит и тибетский языки, совместно была определена тема научной работы и подготовлена кандидатская диссертация монгольского ученого. Ю. Н. Рерих общался с аспирантом Ш. Бирой на монгольском языке, восстанавливал свой разговорный язык. Ш. Бира получил доступ к уникальной коллекции восточных и западных изданий библиотеки профессора по истории Востока и Запада, консультации по восточной культуре.

Уникален выбор темы исследовательской работы молодого монгольского ученого: источниковедение и историография средневековой и новой истории Монголии, тибетоязычная историческая литература. Это редкое научное направление исследований, так как подавляющее большинство исследований было сосредоточено на изучении новейшей истории Монголии и проблем некапиталистического пути развития Монголии в XX в. Встреча с Ю. Н. Рерихом определила на долгие годы тематику научных поисков Ш. Биры. В 1959 г. Ю. Н. Рерих участвовал в Первом съезде монголоведов-филологов в Улан-Баторе, сыграл важную роль в развитии советско-монгольских научных связей и увеличению мирового научного авторитета монгольской науки. Аспирант Ш. Бира сопровождал Ю. Н. Рериха в его поездке по Монголии и помогал устанавливать научные контакты с учеными и ламами, носителями тибетского языка и традиционной восточной культуры. Ю. Н. Рерих активно включился в научную жизнь России и Монголии, опубликовал ряд статей, в том числе «Монголо-тибетские отношения в XIII и XIV вв.» (1958), «Монголо-тибетские отношения в XVI и начале XVII вв.» (1959), "Виктор Викторович Голубев (1878-1945)», «Монгольские заимствования в тибетском языке» (1962), «Сказание о Раме в Тибете» (1960), «Кочевые племена Тибета» (1961). В 1960 г. была опубликована грамматика и краткий очерк литературы («Тибетский язык») [2].

Как известно, Юрий Николаевич Рерих (1902-1960) - ученый-востоковед и монголовед, исследователь народов Центральной Азии с мировым признанием, который глубоко и тонко изучил языки, быт и культуру народов Азии во время экспедиции в 1925-1928 гг., переводил древнейшие восточные трактаты на европейские языки и вводил их в научный оборот. Широта и глубина востоковедных познаний и интересов Ю. Н. Рериха невероятна: языкознание, история, археология, этнология, восточные культы и религии, философия, источниковедение и историография Востока. Ш. Бира выступил последователем научной школы профессора Ю. Н. Рериха, его методологии научных исследований и отношения $к$ рукописному наследию монгольских народов. В научном наследии Ю. Н. Рериха значительное место занимают труды о Тибете, его истории и культуре, поэтому выбор Ш. Бирой темы тибетоязычной исторической литературы представляется логичным и закономерным.

В 1960 г. Ш. Бира издал монографию «Монгольская тибетоязычная историческая литература (XVII-XIX)», редактором которой выступил известный монгольский ученый профессор Ц. Дамдинсурэн, большой знаток литературного на-

\section{Baikal Research Journal}

электронный научный журнал Байкальского государственного университета 
следия монголов [3]. По оценке Ш. Биры, «монголы в прошлом создали, если не целую тибетоязычную культуру, подобно среднеазиатским народам, создавшим арабоязычную культуру в период гегемонии арабов, то во всяком случае, они являются творцами большой тибетоязычной литературы по различным отраслям знания вообще, но и истории в частности. Вся эта литература остается вне поля зрения ученого мира» [Там же, с. 3]. В научный оборот были введены крупные исторические трактаты монгольских ученых: «Ясное зерцало» Лувсанпрэнлэя, исторические труды Самба-Хамба Ишбалжира: «Чойн-жун» (История буддизма), «История Кук-нура»; «История буддизма в Китае» Гомбожава; исторические труды Цахар Гэвш Лувсанчултума: «Житие Цзонхавы», Приложение к «Жћитию», исторические заметки Лувсанчултума; «История буддизма в Монголии» Дармадала. Были сделаны важные уточнения по биографиям данных монгольских ученых, сделана современная оценка их научного вклада и подробное описание основных трудов. Была проделана колоссальная работа по выявлению, систематизации, анализу и характеристике трудов монголов на тибетском языке. В 1964 г. была издана следующая монография ученого «О Золотой книге Ш. Дамдина» [4]. Ш. Дамдин (1867-1937) - один из крупных представителей традиционной исторической школы Монголии, представитель высшего духовенства страны, а «Золотая книга» - одно из лучших произведений, по характеристике Ш. Биры, тибетоязычной монгольской исторической литературы. В работе Ш. Биры представлены творческая биография Ш. Дамдина, структура и анализ его работы, географические и исторические данные, история буддизма в Монголии, история монгольских ханов в освещении Дамдина и история Халхи. Специальный раздел посвящен характеристике основных источников «Золотой книги»: тибетские, монгольские, китайские и европейские источники. Выход в свет этих двух монографий, вопреки основному течению исторической науки Монголии, которая критиковала буддийскую религию и выпускала работы по истории ограничения деятельности и ликвидации буддийской церкви в Монголии в социалистический период (1924-1940) является по-своему уникальным событием.

С 1960 г. Ш. Бира работает в Академии наук Монголии: научным сотрудником, заведующим сектором, директором Института, вице-президентом АН (19731982). В 1960 г. была защищена в Институте востоковедения Академии наук СССР кандидатская диссертация, в 1971 г. - докторская диссертация.

Создание в 1961 г. Академии наук Монголии и академических институтов дали толчок развитию научных исследований, в том числе и исторических наук. В это время в исторической науке работала значительная группа профессиональных историков разных поколений: Б. Ширендыб, Ш. Нацагдорж, Н. Ишжамц, Л. Жамсран, Б. Ринчен, Ч. Далай, Н. Сэроджав, Х. Пэрлээ, М. Санждорж, Ц. Пунцагноров, Ш. Сандаг, Д. Гонгор, Г. Цэрэндорж, Д. Дашжамц; была создана творческая атмосфера научных поисков и формирования современных гуманитарных специалистов. Наиболее близкие творческие отношения были с академиком Ц. Дамдинсурэном, профессором-китаеведом Н. Ишжамцем, Ш. Нацагдоржем. Шла напряженная исследовательская работа по созданию многотомной истории Монголии, публикация исторических и литературных памятников монгольских народов, изучение древней, средневековой и новейшей истории Монголии. Ш. Бира участвует в подготовке разделов однотомной истории Монголии «Истории МНР» (1967), посвященного культуре монголов.

Значительный научный резонанс получила крупная монография академика Ш. Биры «Монгольская историография (XIII-XVII вв.)» (1978), изданная в Москве в издательство "Наука», позднее переведенная на ряд иностранных языков [5]. Данное фундаментальное исследование о становлении и развитии монгольской

\section{Baikal Research Journal}

электронный научный журнал Байкальского государственного университета 
исторической мысли положило начало целой серии работ по монгольской историографии, определило дальнейшие направление научных поисков монгольских и зарубежных монголоведов. Это сочинение, ставшее уже классическим, исследует зарождение исторических знаний и национальной историографии в XIII в., становление и развитие буддийской историографии в XVI-XVII вв., описывает и анализирует исторические хроники «Алтан Тобчи» Лувсанданзана, «Шара Туджи», «Эрдэнийн Тобчи» Саган-Сэцэна, «Историю Асарагчи», золотой фонд монгольской научной и литературной мысли нового времени. Отличительной особенностью Ш. Биры является вдумчивая работа над историческим источником, скрупулезный подход к его анализу и обязательная историографическая оценка, что свидетельствует о высочайшей эрудиции ученого. Книга выдержала испытание временем и прочно вошла в мировое монголоведение и национальную историографию, источниковедение, ее золотой фонд. Было проведено исследование масштабной научной темы, сделавшее академика Ш. Бира основоположником целого научного направления в мировом монголоведении. Позже исследование было переведено на китайский и английский языки, что свидетельствует о серьезном интересе к изданию мировой научной мысли и монголоведения.

Параллельно с Ш. Бирой по данной теме работали российские монголоведы Н. П. Шастина, С. Д. Дылыков, Е. И. Кычанов, Н. Ц. Мункуев, впоследствии данная тема получила свое развитие в публикациях В. Санчирова Ц. П. Ванчиковой, А. Г. Сазыкина, С. ЖК. Дугаровой, А. Д. Цендиной, А. С. Железнякова, В. Л. Успенского. Историографические монголоведные исследования в России проводят М. И. Гольман, Ш. Б. Чимитдоржиев, Д. Б. Улымжиев, В. Д. Дугаров, Ю. В. Кузьмин, О. Н. Полянская, Е. И. Лиштованный, И. В. Кульганек [6; 7].

В 1977-2001 гг. были подготовлены и изданы четыре тома научных статей «Вопросы истории, культуры и историографии Монголии» (БНМАУ-ын түүх, соёл, түүх бичлэгийн асуудал) $(1977,1994,2001$ гг.), которые включили основные публикации академика Биры, посвященные сложным и малоисследованным проблемам монгольской истории и историографии [8].

Особенности монгольской традиционной культуры, место книжной культуры кочевников Монголии постоянно занимают научные интересы Ш. Биры: «Культурное наследие» (1971), «К изучению истории монгольской культуры» (1972), «К вопросу изучения буддийского литературного наследия монголов» (1974), «Вклад кочевых народов в историю и цивилизации Центральной Азии» (1985), «Из истории монгольской культуры» (1988). По мнению Ш. Биры, монгольской книге не менее 700 лет, а «истоки монгольской книги следует связывать с древней традицией кочевых народов высекать слова на камне, фиксируя для потомков наиболее важные события своей истории», а самой ранней камнеписной монгольской книгой следует считать «Чингисов камень» [8, с. 11]. Особо высоко оценивался тибетский язык и тибетоязычная литература в Монголии: «тибетский язык играл в дореволюционной Монголии примерно такую же роль, какую играла в свое время латынь в Европе. Этот язык в сфере интеллектуальной деятельности монголов выступал в качестве главного соперника собственно монгольского языка, вытесняя в известной мере его на второе место. Тибетский язык был в Монголии не только языком религии, но и языком, на котором писали монгольские авторы, стремясь показать свою ученость и эрудицию. Сочинения, написанные монгольскими авторами на тибетском языке, составляют в общей сложности несколько сотен томов. Среди тибетоязычных монгольских авторов немало таких, которым принадлежат сочинения объемом от 5 до 30 томов» [9, с. 16].

C 1987 г. академик Ш. Бира находится на посту Генерального секретаря Международной ассоциации монголоведов, активизирует и расширяет деятельность

\section{Baikal Research Journal}

электронный научный журнал Байкальского государственного университета 
Ассоциации, издает Бюллетень и научные труды монголоведов мира, проводит международные конференции и Международные конгрессы монголоведов. Сложная и многообразная деятельность академика Ш. Биры на ответственном посту международного монголоведения в наиболее трудный период монгольской науки получила высокую оценку международного сообщества. Произошло расширение международного сотрудничества монголоведов мира, усилилась кооперация ученых-монголоведов, произошло существенное сближение и взаимное понимание различных научных школ.

Международная ассоциация монголоведов (MAM) насчитывает более 400 членов из 30 стран. В нее входят Всероссийская ассоциация монголоведов, японская ассоциация монголоведов, американское монгольское общество, корейская ассоциация монголоведения и многие другие научные общества стран мира, индивидуальные члены. Официальные языки: монгольский, русский, английский. МАМ ежегодно издает серию Mongolica и журнал «Вестник монголоведения». С 1992 г. международные конгрессы монголоведов стали проходить под эгидой Президента Монголии, и пять таких форумов были проведены в монгольской столице, организатором международных форумов являлся академик Ш. Бира. Все это свидетельствует об особой роли международной ассоциации монголоведения в поддержке и развитии мирового монголоведения и отношения государственной власти Монголии $к$ науке. Несомненно, что определенная доля повышения статуса МАМ относится и лично к Ш. Бира-гуай.

Академик Ш. Бира в своем творчестве обращается к глобальным и вечным темам человечества. Проблемы мифологии монгольских и алтайских народов, философии жизни народов монгольского мира глубоко интересуют и волнуют ученого, об этом свидетельствуют его книги и многочисленные статьи, посвященные тенгрианству и культу Тенгри у монгольских народов [10]. Академик Ш. Бира выдвинул и постепенно обосновал и развивал концепцию Тенгеризма. Культ почитания Неба у монгольских народов не смог быть вытеснен даже буддизмом, ставшим основной религией у монголов, бурят, тувинцев. Это сложная и многосторонняя научная проблема стала предметом международных конференций, конгрессов и круглых столов ученых мира. По характеристике Ш. Биры, древний культ Неба выделяется в особую категорию и становится верховным божеством в иерархии шаманских божеств. С древнейших времен в Монголии почитали три основных составляющих жизни: человек, тэнгри (небо, космос), и земля (планета). В этой троичности Небо является - отцом, Земля - матерью, Человек - детьми. О взглядах академика Ш. Биры о тэнгэризме подробно писали американская газета «San Francisco Chronicle» ${ }^{1}$, китайская «South China Morning Post» ${ }^{2}$, монгольская «Mongol messenger» ${ }^{3}$, что говорит о серьезном внимании к этой концепции.

По мнению Ш. Биры, идеология тенгеризма прошла три стадии своего развития: в период формирования Монгольского государства в 1206 г., период мировых захватов монголов и период правления хана Хубилая. Ш. Бира защищает великого хана Хубилая от нападок некоторых монгольских исследователей, говоря, что в своей государственной политике под единым небом он не следовал идеям конфуцианства, а использовал экономику и людские ресурсы Китая для расширения границ своих кочевых владений.

Обсуждению и развитию концепции была посвящена серия международных конференций «Тэнгрианство и эпическое наследие народов Евразии: истоки и современность». Тенгрианство рассматривается как важнейшая духовная и миро-

\footnotetext{
${ }^{1}$ Saturday, April 12, 2003.

2 Friday, April 11, 2003.

${ }^{3}$ Wednesday, April 16, 2003.
}

\section{Baikal Research Journal}


воззренческая ценность кочевых народов Центральной Азии, изданы сборники трудов: «Тэнгэризм и монголы», «Проблемы изучения Тенгри в аспекте мировоззренческой культуры», «Материалы III Международной научно-практической конференции в Кызыле, Республике Тыве». В настоящее время тенгриведы из Монголии, России, Болгарии, Кырзыстана, Казахстана разрабатывают и готовят к печати терминологический словарь тенгрианства и готовят четвертую международную конференцию «Тенгрианство и эпическое наследие кочевников Евразии: истоки и современность» в Казахстане, в Астане. Таким образом, научная тема расширяет свои границы и проблематику, что свидетельствует о ее научном признании. Она служит консолидации монгольских и тюркских народов Евразии, более глубокому пониманию роли Евразии в развитии мировой цивилизации.

В последние годы много внимания и сил академик Ш. Бира уделяет изучению творческого наследия знаменитой семьи Рерихов: Н. К. Рериха и Ю. Н. Рериха. По его инициативе было создано Рериховское общество Монголии и музей семьи Рерихов в Улан-Баторе, он активно участвует в международных научных конференциях «Рериховское наследие». Это дань глубокого уважения к творческому наследию великих ученых и художников России, особенно своему Учителю - Юрию Николаевичу Рериху. В 2007 г. директор Государственного Эрмитажа М. Б. Пиотровский торжественно вручил академику Ш. Бира международную премию имени Ю. Н. Рериха.

В 2011 г. Ш. Бира выступил главным редактором уникального издания документов, материалов и научных статей «Рерихи и Монголия» [11], а на Девятом Конгрессе монголоведов в 2016 г. была специальная секция, посвященная творческому наследию семьи Рерихов и научным связям с Монголией, руководителем которой выступал академик Ш. Бира. В научный оборот введены значительный пласт исторических источников, мемуарные и эпистолярные материалы, которые расширяют современное представление о научном наследии и вкладу в мировую цивилизацию и изучение монгольского мира семьей Рерихов. Происходит и значительное укрепление российско-монгольских научных связей, которые нуждаются в своем развитии и новом содержании.

Ш. Бира-гуай - истинный монгольский интеллигент, человек высокой духовности и культуры, доступный в общении для ученых, студентов и начинающих монголоведов, которые обращаются к нему за советом и поддержкой. Хорошо запомнились встречи с академиком Ш. Бира в 1977-1979 гг., 1988-1989 гг. в Монголии, когда он читал лекции и проводил беседы со студентами-практикантами исторического факультета Иркутского университета о состоянии и проблемах монгольского и мирового монголоведения. Поражала его увлеченность научными исследованиями, простота изложения сложного гуманитарного материала и доступность общения с молодыми людьми. В мировом монголоведении академик Ш. Бира имеет репутацию высочайшего научного авторитета и профессионализма.

Академик Шагдарын Бира-гуай — признанный лидер современной монгольской гуманитарной элиты. Заслуженный деятель Академии наук Монголии, почетный доктор МГИМО, почетный профессор университета Внутренней Монголии, почетный член общества изучения Центральной Азии США, почетный доктор Института востоковедения РАН. Его труды и идеи получили мировое признание, опубликованы на основных языках мира, активно изучаются в центрах монголоведения мира, с интересом читаются любителями монгольской истории и культуры. Академик Ш. Бира читал лекции в ведущих мировых центрах: Королевском азиатском обществе Великобритании, Институте востоковедения РАН, Институте социальных наук Франции, Токийском университете изучения иностранных языков Азии, Африки, Боннском университете (Германия), Пекинском университете, Музее Рериха

\section{Baikal Research Journal}


в США и других престижных научных и учебных центрах мирового монголоведения. По линии ЮНЕСКО Ш. Бира участвовал в фундаментальных исследованиях: «История цивилизации Центральной Азии» (в 6 томах), «История развития культуры и науки человечества» (в 7 томах), в которых он подготовил разделы по истории и культуре Монголии. В декабре 2006 г. в столице Франции Париже, в штаб-квартире ЮНЕСКО состоялась презентация 6 томов «Истории цивилизации Центральной Азии», во время которой Генеральный директор ЮНЕСКО Коичиро Мацуда торжественно вручил монгольскому академику Ш. Бире и его коллегам-соавторам юбилейную медаль «60-летие ЮНЕСКО» и почетные дипломы.

Академик Ш. Бира и сегодня полон творческих сил и замыслов, успешно завершает начатые ранее исследования, готовит к публикации многотомное собрание сочинений, о котором принято решение на правительственном уровне Монголии. Хочется пожелать почитаемому во всем мире академику Ш. Бира-гуай доброго здоровья, благополучия и дальнейших творческих успехов.

Список использованной литературы

1. Хатанбаатар Д. Хувь тавилангийн солбилцол (Координаты судьбы) / Д. Хатанбаатар. - Улан-Батор : Цаг-Зуг, 2008. - 187 с.

2. Рерих Ю. Н. Тибет и Центральная Азия: статьи, лекции, переводы / Ю. Н. Рерих. Самара : Агни, 1999. - 368 с.

3. Бира Ш. Монгольская тибетоязычная историческая литература (XVII-XIX) / Ш. Бира. - Улан-Батор : Гос. изд-во, 1960. - 271 с.

4. Бира Ш. О «Золотой книге» Ш. Дамдина / Ш. Бира. - Улан-Батор : Изд-во Акад. наук МНР, 1964. - $153 \mathrm{c}$.

5. Бира Ш. Монгольская историография (XIII-XVII вв.) / Ш. Бира. - М. : Наука, 1978. $-320 \mathrm{c}$.

6. Дугаров В. Д. Российская историография истории Монголии / В. Д. Дугаров ; науч. ред. Л. В. Курас. - Улан-Удэ : Изд-во Бурят. гос. ун-та, 2015. - 376 с.

7. Суходолов А. П. Монголия и русско-монгольские отношения первой половины $\mathrm{XX}$ века: проблемы истории историографии / А. П. Суходолов, Ю. В. Кузьмин, - Иркутск : Изд-во Байкал. ун-та, 2016. - 318 с.

8. Бира Ш. Вопросы истории, культуры и историографии Монголии : сб. тр. / Ш. Бира. - Улан-Батор : Интерпресс, 2001. - 528 с.

9. Книга Монголии / сост. Н. Цаагач. - М. : Книга, 1988. - Вып. 24. - 384 с. (Альманах библиофила).

10. Бира Ш. Монголын тэнгэрийн узэл (Тэнгрианство Монголии) / Ш. Бира. - Улан-Батор : Содпресс, 2011. - 482 с. $510 \mathrm{c}$.

11. Рерихи и Монголия : сб. ст. / отв. ред. Ш. Бира. - Улан-Батор : Содпресс, 2011. —

\section{References}

1. Hatanbaatar D. Huv tavilangiyn solbiltsol [Coordinates of Destiny]. Ulaanbaatar, CagZug Publ., 2008. 187 p. (In Mongolian).

2. Roerich Yu. N. Tibet $i$ Tsentralnaya Aziya: stati, lektsii, perevodyi [Tibet and Central Asia: Articles, Lectures, Translations]. Samara, Agni Publ., 1999. 368 p.

3. Bira Sh. Mongolskaya tibetoyazyichnaya istoricheskaya literatura (XVII-XIX) [Mongolian Tibetan Historical Literature (XVII-XIX)]. Ulaanbaatar, State Publ. House, 1960. 271 p.

4. Bira Sh. $O$ "Zolotoi knige» Sh. Damdina [On the «Golden Book» of Sh. Damdin]. Ulaanbaatar, Mongolian Academy of Sciences Publ., 1964. 153 p.

5. Bira Sh. Mongolskaya istoriografiya (XIII-XVII vv.) [Mongolian historiography (XIII-XVII centuries) Moscow, Nauka Publ., 1978. 320 p.

6. Dugarov V. D.; Kuras L. V. (ed.). Rossiyskaya istoriografiya istorii Mongolii [Russian historiography of Mongolia's history]. Ulan-Ude, Buryat State University Publ., 2015. 376 p.

7. Suhodolov A. P., Kuzmin Yu. V. Mongoliya i russko-mongolskie otnosheniya pervoy polovinyi XX veka: problemyi istorii istoriografii [Mongolia and Russian-Mongolian Relations

\section{Baikal Research Journal}

электронный научный журнал Байкальского государственного университета 
in the first half of the 20th Century: Problems of historiography]. Irkutsk, Baikal State University Publ., 2016. 318 p.

8. Bira Sh. Voprosyi istorii, kulturyi i istoriografii Mongolii [Issues of history, culture and historiography of Mongolia]. Ulaanbaata, Interpress, 2001. $528 \mathrm{p}$.

9. Tsaagach N. (ed.). Kniga Mongolii [The Book of Mongolia]. Moscow, Kniga Publ., 1988. 384 p. Series Almanah bibliofila, iss. 24.

10. Bira Sh. Mongolyn tengeriin uzel [Tengriism of Mongolia]. Ulaanbaatar, Interpress, 2001. 482 p. (In Mongolian).

11. Bira Sh. (ed.). Rerikhi i Mongoliya [The Roerichs and Mongolia]. Ulaanbaatar, Adpress, 2011. $510 \mathrm{p}$.

\section{Информация об авторах}

Суходолов Александр Петрович - доктор экономических наук, профессор, действительный член Академии военных наук, ректор, Байкальский государственный университет, 664003, г. Иркутск, ул. Ленина, 11, e-mail: rector@bgu.ru.

Кузьлин Юрий Васильевич - доктор исторических наук, профессор, кафедра мировой экономики и международного бизнеса, Байкальский государственный университет, 664003, г. Иркутск, ул. Ленина, 11, e-mail: kuzminuv@ya.ru.

Василенко Виктория Александровна - кандидат исторических наук, доцент, кафедра прикладной информатики и документоведения, Иркутский государственный университет, 664003, г. Иркутск, ул. Карла Маркса, 1, e-mail: vasil-vic79@уandex.ru.

\section{Authors}

Alexandr P. Sukhodolov - Doctor habil. (Economics), Full Member of the Academy of Military Sciences, Professor, Rector, Baikal State University, 11 Lenin St., 664003, Irkutsk, Russian Federation; e-mail: rector@bgu.ru.

Yury V. Kuzmin - Doctor habil. (History), Professor, Chair of World Economy and International Business, Baikal State University, 11 Lenin St., Irkutsk, Russian Federation; e-mail: kuzminuv@ya.ru.

Viktorya A. Vasilenko - PhD in History, Associate Professor, Chair of Applied Computer Science and Document Science, Irkutsk State University, 1 Karl Marx St. 664003, Irkutsk, Russian Federation; e-mail: vasil-vic79@yandex.ru.

\section{Библиографическое описание статьи}

Суходолов А. П. Проблемы истории, источниковедения и историографии Монголии: к 90-летию академика Шагдарын Бира / А. П. Суходолов, Ю. В. Кузьмин, В. А. Василенко // Baikal Research Journal. — 2017. — T. 8, № 2. - DOI: 10.17150/2411-6262.2017.8(2).1.

\section{Reference to article}

Sukhodolov A. P., Kuzmin Yu. V., Vasilenko V. A. Problems of history, source studies and historiography of Mongolia: on 90-th anniversary of academician Shagdaryn Bira. Baikal Research Journal, 2017, vol. 8, no. 2. DOI: 10.17150/2411-6262.2017.8(2).1. (In Russian).

\section{Baikal Research Journal}

